\title{
Impact of Service Quality, Price, and Brand on Loyalty with the mediation of Customer Satisfaction on Pos Ekspres in East Java
}

\author{
Mohamad Dimyati \\ The Faculty of Economics and Business, Jember University, Indonesia \\ J. Kalimantan No. 37 Jember, East Java, Indonesia Post Code 68121 \\ Email: dim_ekounej@yahoo.co.id

\section{N. Ari Subagio} \\ The Faculty of Economics and Business, Jember University, Indonesia \\ Jl. Kalimantan No. 37 Jember, East Java, Indonesia Post Code 68121 \\ Email: ari.subagio@gmail.com
}

Doi:10.5901/mjss.2016.v7n4p

\begin{abstract}
The study examines the effect of service quality, price, brand image on customer satisfaction. This study also investigates the effect of loyalty, customer satisfaction on customer loyalty. The population is the customers who use the express post services in East Java, which consists of walk-in customers and account customer. Total sample of 133 respondents is drawn using purposive sampling method, the respondents came from Surabaya, Malang and Jember representing large cities, medium and small. The model analysis is structural equation modeling (SEM). The results showed that: good quality of service that meet customer expectations significantly affects customer satisfaction and loyalty, or vice-versa, a good price (according to the quality, affordable, and competitive) significantly influence the improvement of customer satisfaction and loyalty, or vice-versa, brand image has significant positive effect on customer satisfaction or vice-versa, increasing customer satisfaction significantly influence on increasing customer loyalty or vice-versa but the brand image significantly has no direct effect on customer loyalty.
\end{abstract}

Keywords: service quality, price, brand image, customer satisfaction, customer loyalty

\section{Introduction}

The company can retain their customers with providing good services at the time of sale or at after-sales service. Good service quality will satisfied the customers and leads to the creation of customer loyalty. According to Kotler and Keller (2006) quality is the totality and characteristics of a product or service that is related to its ability to satisfy as promises. Quality is something that is felt by customers in order to satisfy their expectation. Good service is a service that is capable of providing satisfaction to customers or able to provide service that exceeds their expectations.

Fullerton and Taylor (2002), Caruana (2002), Hidayat (2009), Jahanshahi et al. (2011), showed that the quality of service has an influence on satisfaction. Furthermore Dimyati (2011) showed that service quality has positive influence on customer satisfaction. Bei and Chiao (2001) also found an indication that the service quality and customer satisfaction happens in sequence and therefore satisfaction affects customer loyalty.

According to Nirvana (2006), the quality of service is dynamic and changes with the demand of the customers. Furthermore Widjaja (2002) states that the character of Indonesia customers still have a high tendency to be served by employees. Although it has many research studies on service quality, but it is still needed to conduct further research especially for accommodate the specific characteristics of business services in Indonesia in which it has unique customers.

Price is very important aspect for customers because it will be a guide to measure the fit between the benefits of the product received by the sacrifices that have been given either in the form of monetary and non-monetary aspects. Customers will also use price as one of the standard level of their satisfaction. Research Voss et al. (1998), and Bei and Chiao (2001), found that the price has a positive significant effect on customer satisfaction. These results are in contrast to studies Ostrowski et al. (1993), Mahmud et al. (2013), which found the price factor has no effect on customer satisfaction.

Company uses product differentiation to create value and brand image as well. Product differentiation provides an 
option for customer so they can choose which product will suit their need. Most companies today understand that many customers are not loyal only to one particular brand (Dekimpe, et al., 1997; Bennett and Rundle, 2005; Kapferer, 2005). Aaker and Keller (1990), Tu et al. (2012), Thakur and Singh (2012), found that the brand image has a positive effect on satisfaction. Zeithaml and Bitner (1996) shows that customer satisfaction is exclusively influenced by service quality, product quality, price, situational factors and human factors. Further research of Zeithaml, Parasuraman, and Berry (1996), found that the quality of service can directly influence on loyalty. This reality shows that customer satisfaction and loyalty are an important issue for all organizations, and is used as a marketing standard to improve company performance (Bennett and Rundle, 2004).

Customer expresses their loyalty with repeat the purchase from company. Bennett and Rundle (2004), and Schultz, (2005), state that customers who feel satisfied by a product or service will form a loyal behavior. This behavior will lead to repetitive purchases and share a positive word of mouth. This finding is in line with Selnes (1993), which states that customer loyalty can be formed if the customer is satisfied with the brand or the level of service received and intend to continue the relationship.

Caruana (2002), Aryani and Rosita (2010), found that the service quality does not directly influence customer loyalty, but it goes through the mediation of customer satisfaction. Dimyati (2015) showed that customer satisfaction is a significant positive effect on customer loyalty. Then Yulisetiarini (2016) found that the perceived feeling of satisfied customers will increase customer loyalty. Referring to the various results of previous empirical studies it can be concluded that services quality, pricing, brand image, customer satisfaction and loyalty are important to customers and companies.

Postal business is a low entry barrier industry, it is said very easy to enter because to get into this business is not required high capital or any special skills. Indonesian Act No. 38 year 2009 about the Postal service (Article 4 paragraph 2), presents a great opportunity for the public to conduct a postal service. The owner of this business can be state owned, local state enterprises, private enterprises and cooperatives. The act brings postal industry in Indonesia to open market competition, which means that competition between postal operators cannot be avoided.

Private courier companies are quite aggressive in grabbing market share of PT Pos Indonesia (Persero). There are a lot of operator providing postal service in Jember, such as TIKI, JNE, Kerta Gaya Pusaka (KGP), Indo Logistics and still there are several other local courier. This situation lead to high competition and the postal business player should give a serious attention on it.

\section{Literature Review and Conceptual Framework}

\subsection{Service Quality}

Kotler (2008) defines a service as any performance or action that either party can offer to the other party, which is essentially intangible and does not result in any ownership. Services can be attributed to physical products, but can also not associated with physical product. The quality of service according to Parasuraman, Zeithaml and Berry (1988) is a form of attitude, related but not the same as satisfaction, as a result of the comparison between the expectations of the performance. Quality of service can also be defined as customer vote on the advantages or privileges of a product or service as a whole (Zeithaml, 1988). Service quality can also be interpreted as a caring company towards the customers (Dimyati, 2011). Parasuraman, Zeithaml, and Berry (1985) defines quality of service as a thorough assessment or attitude concerning the superiority of the service.

According to Parasuraman, Zeithaml, and Berry (1998), quality of service includes five dimensions: Tangibles, Reliability, Responsiveness, Assurance, and Empathy. The measurement of this indicator is using the service performance (SERVPERF) which assesses the performance of the personnel and all the facilities used in providing service to customers (Cronin and Taylor, 1992).

\subsection{Price}

Price is an important component of a product, because it will affect manufacturers' profit. Price is also a consideration of consumers to buy, so it needs special considerations for determining that price. According to Kotler (2008), the price is the sum of all the values given by the customer to benefit or the benefit of having or using a product or service. In addition, the price can be interpreted a number of money (plus a few items that may be) required to get the number of combinations of goods along with services (Swastha and Irawan, 2005). Prices are also defined amount of money charged or imposed on a product or service (Simamora, 2003). 
According to Kotler and Armstrong (2012), there are four indicators that characterize the price is; (1) affordability, (2) the suitability of the price with the quality of the products, (3) price competitiveness, and (4) the suitability of the price of the benefit.

\subsection{Brand Image}

Keller (1993) defines brand image as the customers 'perception of a brand that is described in the existing brand associations in consumers' minds. Hsieh, Pan and Setiono (2004), said that the image of a successful brand is a brand image that allows consumers to identify needs that can be satisfied with a brand and comparing with other competitors. Brand image can be measured through five indicators: (1) attributes, which describe the characteristics inherent in the product or service, (2) functional, that describes the benefits that will be received when consuming products or services, (3) symbolic, depicting consumer desire for products or services, (4) the experience, describing the experience that consumers consume products or services, (5) overall evaluation, which illustrates the subjective assessment of consumers to products or services (Shimp, 2003).

\subsection{Customer Satisfaction}

Customers face a multi-faceted range of products to satisfy specific needs, and to satisfy their needs, customers will choose among a lot of these products. In order to win the competition, company should really have the ability to provide satisfaction to its customers. Satisfaction is the output of marketing activities and serves as a link in the purchase process. Consumer satisfaction is a function of the expectations of the buyer of the products/services with perceived performance. Kotler and Keller (2006), states that customer satisfaction in one's feel of happiness or upset as a result of a comparison between the performace of a product and his/her expectation. If the performance fails to meet expectations, the customer is not satisfied, if the performance in accordance with expectation, then the customer is satisfied and if the performance exceeds expectations, the customer was very satisfied. Satisfaction can also be defined as the evaluation of the alternative selected to meet or surpass expectations (Engel et al., 1993).

Customer satisfaction can be measured by three indicators: (1) overall satisfaction, (2) confirmation of expectation, the level of compatibility between the performance expectations, and (3) comparison to the ideal, namely the performance of the product in comparison with the ideal product according to consumer perceptions (Fornell et. al., 1996).

\subsection{Customer Loyalty}

Customer loyalty to a product is reflected through the customer's habit to purchase a product continuously, therefore, in order to understand the needs and expectations customer'a as weel as to achieve the objective, a company needs to observe customer loyalty. A loyal customer tends to repurchase the product, purchase among the product lines, recommend the product to others, and be able to show the quality of products produced by other similar companies (Griffin, 2002). Company is required not only to observe the customer's habit of repurchase, but also to learn where they buy, how they buy, and under what condition these products must be purchased. Customer loyalty in the context of the marketing of services, defined as a response that is closely associated with a pledge or a promise to uphold the commitment underlying the sustainability of relationships, and usually reflected in the purchase of a recurring basis from service providers together on the basis of dedication and constraints pragmatic (Tjiptono, 2012).

Customer loyalty in the process caused by satisfaction, but the level of customer satisfaction that is capable of forming loyalty is actually a certain level of satisfaction that can not be provided by other service providers, namely delight or surprising (Oliver, 1997). The level of loyalty which actually begins with the assessment of very satisfied with what it receives from the company (Jones and Sasser, 1995). The main cause of become loyal customers is if they are very satisfied with the services received.

Zeithaml, Parasuraman, and Berry (1996) states that there are three indicators of loyalty: (1) say positive things, is to say something positive thing about the product is consumed, (2) recommend to someone, is recommending the product that has been consumed to a friend, (3) repurchase intention, is made to re-purchase a product that has been consumed.

Based on the purpose of research and literature reviews, it can be prepared the conceptual framework of the study as presented in Figure 1. Referring to the conceptual framework, this study will test seven hypothesis as follows:

1. Quality of service is significant positive effect on customer satisfaction Pos Ekspres in East Java 
2. The prices of services significant positive effect on customer satisfaction Pos Ekspres in East Java

3. The image of a service mark significant positive effect on customer satisfaction Pos Ekspres in East Java

4. The quality of service is a significant positive effect on customer loyalty Pos Ekspres in East Java

5. The prices of services significant positive effect on customer loyalty Pos Ekspres in East Java

6. The image of a service mark significant positive effect on customer loyalty Pos Ekspres in East Java

7. Customer satisfaction services significant positive effect on customer loyalty Pos Ekspres in East Java

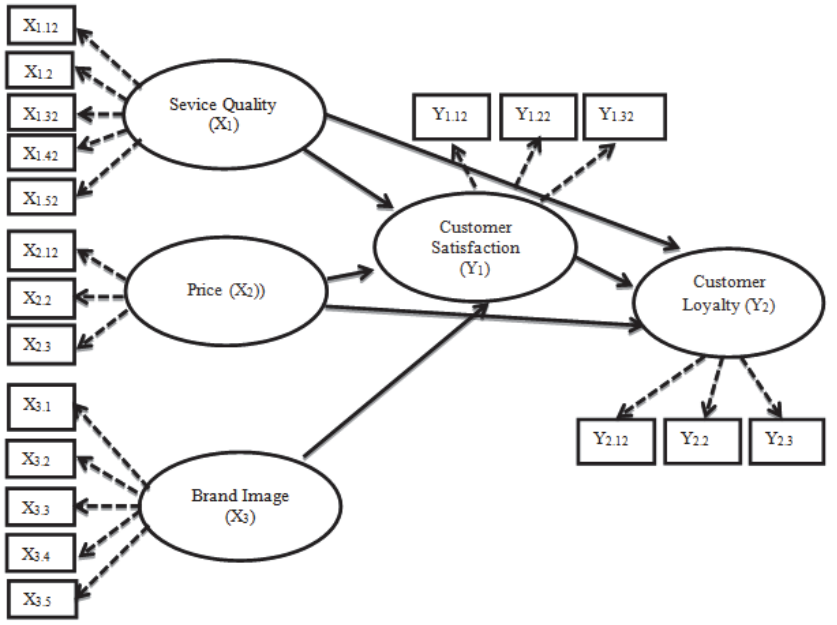

Figure 1: Conceptual Framework

\section{Methodology}

The design of this study is confirmatory research with a population of customers who use the express post services in East Java, which consists of walk-in customers and accounts customer. Walk-in customer is a customer who is not bound by the Agreement of Cooperation (MCC), charged at the rate of already published rate and paid at the time of the transaction. These types of customers are not recorded in the Management Information System (MIS) Post Office, so it is unknown for certain amount. Corporate customers are customers who are tied with the Agreement of Cooperation (MCC), subject to a negotiable tariff and the payment can be paid in accordance with the agreement.

The total sample of 133 respondents is determined by the number of indicator variables (19) multiplied by 7 refers to Ferdinand (2006) that states in order to determine the sample size of a study is the number of indicators used in the study variables multiplied by 5 -10. Furthermore Ghozali (2004) states that the appropriate sample size in the equation model SEM is between 100-200 samples. The variables analyzed in this study consisted of three exogenous variables, the quality of service, price, and brand image. One intervening variables, customer satisfaction and one an endogenous variable, customer loyalty.

Service Quality (X1) is measured through an indicator variable refers to the opinion of five Parasuraman, Zeithaml and Berry (1998). Furthermore, the scale of measurement using a SERVPERF scale developed by Cronin and Taylor (1992). The SERVPERF scale has been selected as it will measure the perception or assessment of the quality of service that customers receive. SERVPERF is more appropriate than SERVQUAL because it measures the service quality based on the performance quality of service. Price (X2) measured by four variables indicators refer to the opinion Kotler and Armstrong (2012). Brand image (X3) is measured through indicators refers to the opinion of five variables (Shimp, 2003). Customer satisfaction (Y1) is measured through three indicator variables refers to the opinion of Fornell et al. (1996). Customer loyalty (Y2) is measured through three indicator variables referring to opinion of Zeithaml, Parasuraman, and Berry (1996).

Thus five latent variables is measured by using Likert Scale with five answer choices of 1-5. This scale is an interval scale (Indriantoro and Supomo, 2002; Sekaran, 2003). Hypotheses' testing is done by Structural Equation Modeling (SEM) with AMOS version 18. 


\section{Results and Discussion}

\subsection{Validity Test and Instruments Reliability}

Table 1 shows the results of validity and reliability of the instrument with a confirmatory factor analysis which shows that all indicators of latent variables are valid and reliable. It's indicated by the t(CR) value for the loading factor $(\lambda)$ of each variable indicator of all latent variables studied is greater than the critical value (CR> 1.96) at the 0.05 level, with a probability value of less than á $(P<0.05)$ and contruct reliability is greater than the recommended value $(\geq 0,70)$.

Table 1: Validity and Reliability Test Results

\begin{tabular}{|c|c|c|c|c|c|c|c|}
\hline \multirow{2}{*}{ No } & \multirow{2}{*}{ Variabel Indicator } & \multicolumn{5}{|c|}{ Validity Test } & \multirow{2}{*}{ Construct Reliability } \\
\hline & & Loading factor & $\mathrm{CR}$ & $\mathrm{P}$ & Remark & GFI & \\
\hline 1. & $\mathrm{X}_{11}$ & 0,842 & 5,107 & $\star \star \star$ & Valid & & \\
\hline 2. & $X_{12}$ & 0,797 & 4,816 & 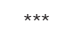 & Valid & & \\
\hline 3. & $\mathrm{X}_{13}$ & 0,835 & 5,031 & $\star \star *$ & Valid & & 0,912 \\
\hline 4. & $\mathrm{X}_{14}$ & 0,759 & 4,682 & $\star \star *$ & Valid & & \\
\hline 5. & $X_{15}$ & 0,872 & * & * & Valid & & \\
\hline 6. & $\mathrm{X}_{21}$ & 0,809 & 3,844 & 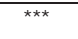 & Valid & & \\
\hline 7. & $X_{22}$ & 0,788 & 3,685 & 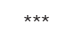 & Valid & & 0,854 \\
\hline 8. & $X_{23}$ & 0,842 & * & * & Valid & & \\
\hline 9. & $X_{31}$ & 0,778 & 3,761 & $\star \star \star$ & Valid & 0,918 & \\
\hline 10. & $X_{32}$ & 0,791 & 3,920 & *** & Valid & Valid & \\
\hline 11. & $X_{33}$ & 0,748 & 3,698 & 0,013 & Valid & Undimensional & 0,884 \\
\hline 12. & $X_{34}$ & 0,704 & 2,876 & 0,004 & Valid & & \\
\hline 13. & $X_{35}$ & 0,864 & * & * & Valid & & \\
\hline 14. & $Y_{11}$ & 0,881 & * & * & Valid & & \\
\hline 15. & $Y_{12}$ & 0,807 & 4,524 & $\star \star \star *$ & Valid & & 0,865 \\
\hline 16. & $Y_{13}$ & 0,787 & 4,580 & 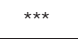 & Valid & & \\
\hline 17. & $Y_{21}$ & 0,874 & & * & Valid & & \\
\hline 18. & $Y_{22}$ & 0,813 & 3,625 & $\star * *$ & Valid & & 0,859 \\
\hline 19. & $Y_{23}$ & 0,768 & 3,511 & 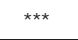 & Valid & & \\
\hline
\end{tabular}

Souces: Data Analysis with AMOS Version 18

\subsection{Descriptive Analysis}

The following tables show the detailed description of the characteristics of respondents. Table 2 shows the majority of respondents were women, 68 people or $51.13 \%$ of the total. These data provide information that women use more of the Post Express delivery services than men. This is reasonable because the population of women more than men in Indonesia.

Table 3 provides information that the majority of respondents aged 31 years to 40 years that is equal to 74 or 55 , $64 \%$ of the total respondents. Respondents in the group is an age group that has many productive activities in their everyday life.

Table 2: Respondents Characteristics by Gender

\begin{tabular}{|c|c|c|}
\hline Gender & Number of people & Percentage (\%) \\
\hline Man & 65 & 48,87 \\
\hline Woman & 68 & 51,13 \\
\hline Total & 133 & 100 \\
\hline
\end{tabular}

Sources: Primary data 
Table 3: Respondents Characteristics by Age

\begin{tabular}{|c|c|c|}
\hline Age & Number of people & Percentage (\%) \\
\hline $0-19$ year & 22 & 16,54 \\
\hline $20-30$ year & 18 & 13,54 \\
\hline $31-40$ year & 74 & 55,64 \\
\hline $41-50$ year & 15 & 11,28 \\
\hline$>50$ year & 4 & 3,01 \\
\hline Total & 133 & 100 \\
\hline
\end{tabular}

Sources: Primary data

Based on the Table 4 it is known that the majority of respondents has ever used the services of Post Express as much as 2 to 3 times or by 74 votes or $55.63 \%$ of the total respondents. This is an indication that all respondents have used / repurchase services Ekspress Pos.

Table 4: Respondents Characteristics Based on Frequency of Use of Postal Services Express

\begin{tabular}{|c|c|c|}
\hline Frequency of use & Number of people & Percentage (\%) \\
\hline 2 - 3 times & 74 & 55,63 \\
\hline $4-5$ times & 35 & 26,31 \\
\hline$>5$ times & 24 & 18,06 \\
\hline Total & 133 & 100 \\
\hline
\end{tabular}

Sources: Primary data

Table 5 presents the answers of respondents for latent variable indicators in detail.

Table 5 shows the respondent's answer to the judgment of each indicator Service Quality (X1) as follows:

1. Tangible (X1.1), $87.22 \%$ of respondents agree (Score 4 ) and $12.78 \%$ respondents answered strongly agree (score 5). This indicates that, all respondents (100\%) assess the tangible performance indicators are in accordance with the wishes of the customer.

Table 5: Respondents Frequency Distribution Rate on Service Quality (X1)

\begin{tabular}{|c|c|c|c|c|c|c|c|c|c|c|c|}
\hline \multirow{3}{*}{ Indicators } & \multicolumn{10}{|c|}{ Respondents Score } & \multirow{3}{*}{ Total } \\
\hline & \multicolumn{2}{|c|}{1} & \multicolumn{2}{|c|}{2} & \multicolumn{2}{|c|}{3} & \multicolumn{2}{|c|}{4} & \multicolumn{2}{|c|}{5} & \\
\hline & $\mathrm{F}$ & $\%$ & $F$ & $\%$ & $\mathrm{~F}$ & $\%$ & $\mathrm{~F}$ & $\%$ & $\mathrm{~F}$ & $\%$ & \\
\hline$X_{1.1}$ & - & - & - & - & - & - & 116 & 87,22 & 17 & 12,78 & 133 \\
\hline$X_{1.2}$ & - & - & - & - & 2 & 1,50 & 113 & 84,96 & 18 & 13,53 & 133 \\
\hline $\mathrm{X}_{1.3}$ & - & - & - & - & 1 & 0,75 & 117 & 87,97 & 15 & 11,28 & 133 \\
\hline$X_{1.4}$ & - & - & - & - & - & - & 117 & 87,97 & 16 & 12,03 & 133 \\
\hline $\mathrm{X}_{1.5}$ & - & - & - & - & - & - & 111 & 83,46 & 22 & 16,54 & 133 \\
\hline
\end{tabular}

Sources: Primary data

2. Reliability (X1.2) by $1.5 \%$ of respondents answered neutral (score 3), $84.96 \%$ answered agree, and $13.53 \%$ answered strongly disagree. This shows that the majority of respondents $(98.46 \%)$ assess the reliability of performance indicators are in accordance with the wishes of the customer.

3. Responsiveness (X1.3), $0.75 \%$ neutral answer, $87.97 \%$ answered agree, and $11.28 \%$ answered strongly disagree. This condition indicates that the majority of respondents (99.25\%) assess the responsiveness of performance indicators already are in accordance with the wishes of the customer.

4. Assurance (X1.4), by $87.97 \%$ answered agree, and $12.03 \%$ answered strongly agreed, that all respondents $(100 \%)$ assess the performance indicators assurance are in accordance with the wishes of the customer.

5. Empathy (x1.5), which amounted to $83.46 \%$ and $16.54 \%$ answered agree answered strongly agreed, that all respondents (100\%) assess the performance indicator of empathy is in conformity with the wishes of the customer. 
Table 6: Respondents Frequency Distribution Rate on Price (X2)

\begin{tabular}{|c|c|c|c|c|c|c|c|c|c|c|c|c|}
\hline \multirow{3}{*}{ Indicators } & \multicolumn{9}{|c|}{ Respondents Score } & \multirow{2}{*}{ Total } \\
\cline { 2 - 14 } & \multicolumn{2}{|c|}{1} & \multicolumn{2}{|c|}{2} & \multicolumn{3}{|c|}{3} & \multicolumn{2}{|c|}{4} & \multicolumn{2}{|c|}{5} & \\
\cline { 2 - 13 } & $\mathrm{F}$ & $\%$ & $\mathrm{~F}$ & $\%$ & $\mathrm{~F}$ & $\%$ & $\mathrm{~F}$ & $\%$ & $\mathrm{~F}$ & $\%$ & \\
\hline $\mathrm{X}_{2.1}$ & - & - & - & - & 2 & 1,50 & 102 & 76,69 & 17 & 12,78 & 133 \\
\hline $\mathrm{X}_{2.2}$ & - & - & - & - & 2 & 1,50 & 104 & 78,20 & 18 & 13,53 & 133 \\
\hline $\mathrm{X}_{2.3}$ & - & - & - & - & 1 & 1,50 & 108 & 81,20 & 15 & 11,28 & 133 \\
\hline
\end{tabular}

\section{Sources: Primary data}

Based on Table 6 it can be seen that respondent's assessment of each indicator price (X2) as follows:

1. Price Affordability (X2.1), amounting to $1.5 \%$ of respondents answered neutral, $76.69 \%$ answered agree, and $21.81 \%$ answered strongly agree, so it is known that the majority of respondents $(98.50 \%)$ assess the price Pos Ekspres affordable.

2. Price Conformity with Quality (X2.1), which is $1.5 \%$ answered neutral, $78.2 \%$ answered agree, and $20.3 \%$ answered strongly agreed, that the majority of respondents (98.50\%) assess the appropriate price with quality.

3. Price Competitiveness (X2.3), which is $1.5 \%$ answered neutral, $81.2 \%$ answered agree, and $17.29 \%$ answered strongly agree, which means that the majority of respondents (98.50\%) assess the price has been able to compete.

Table 7: Respondents Frequency Distribution Rate on Brand Image (X3)

\begin{tabular}{|c|c|c|c|c|c|c|c|c|c|c|c|}
\hline \multirow{3}{*}{ Indicators } & \multicolumn{10}{|c|}{ Respondents Score } & \multirow{3}{*}{ Total } \\
\hline & \multicolumn{2}{|c|}{1} & \multicolumn{2}{|c|}{2} & \multicolumn{2}{|c|}{3} & \multicolumn{2}{|c|}{4} & \multicolumn{2}{|c|}{5} & \\
\hline & $\mathrm{F}$ & $\%$ & $\mathrm{~F}$ & $\%$ & $\mathrm{~F}$ & $\%$ & $\mathrm{~F}$ & $\%$ & $\mathrm{~F}$ & $\%$ & \\
\hline$X_{3.1}$ & - & - & - & - & 1 & 0,75 & 114 & 85,71 & 18 & 13,53 & 133 \\
\hline$X_{3.2}$ & - & - & - & - & 3 & 2,26 & 110 & 82,71 & 20 & 15,04 & 133 \\
\hline$X_{3.3}$ & - & - & - & - & 4 & 3,01 & 103 & 77,44 & 26 & 19,55 & 133 \\
\hline$X_{3.4}$ & - & - & - & - & 1 & 0,75 & 109 & 81,95 & 23 & 17,29 & 133 \\
\hline$X_{3.5}$ & - & - & - & - & - & - & 109 & 81,95 & 24 & 18,05 & 133 \\
\hline
\end{tabular}

Sources: Primary data

Table 7 shows the respondents' answers for Brand Image (X3) indicators,

1. Attributes (X3.1), $0.75 \%$ of respondents answered neutral, $85.71 \%$ answered agree, and $13.53 \%$ answered strongly disagree. These data indicate that the majority of respondents (99.25\%) assess indicators of positive attributes (good and very good).

2. Functional (X3.2), $2.26 \%$ neutral answer, $82.71 \%$ answered agree, and $15.04 \%$ answered strongly disagree. This means that the majority of respondents (97.74\%) assess the functional indicators of positive (good and very good).

3. Symbolic (X3.3), 3.01\% neutral answer, $77.44 \%$ answered agree, and $19.55 \%$ answered strongly agreed, that the majority of respondents (96.99\%) assess the positive symbolic indicator (good and very good).

4. Experience (X3.4), $0.75 \%$ of respondents answered neutral, $81.95 \%$ answered agree, and $17.29 \%$ answered strongly disagree. Circumstances indicate that the majority of respondents (99.25\%) assess indicators of positive experiences (good and very good).

5. Overall Assessment (X3.5), ie $81.95 \%$ answered agree, and $18.05 \%$ answered strongly agree, so that all of the respondents (100\%) rate the overall assessment indicators are positive (good and very good).

Table 8: Respondents Frequency Distribution Rate on Customer Satisfaction (Y1)

\begin{tabular}{|c|c|c|c|c|c|c|c|c|c|c|c|}
\hline \multirow{3}{*}{ Indicators } & \multicolumn{10}{|c|}{ Respondents Score } & \multirow{3}{*}{ Total } \\
\hline & \multicolumn{2}{|c|}{1} & \multicolumn{2}{|c|}{2} & \multicolumn{2}{|c|}{3} & \multicolumn{2}{|l|}{4} & \multicolumn{2}{|l|}{5} & \\
\hline & $F$ & $\%$ & $\mathrm{~F}$ & $\%$ & $F$ & $\%$ & $\mathrm{~F}$ & $\%$ & $\mathrm{~F}$ & $\%$ & \\
\hline$Y_{1.1}$ & - & - & - & - & 4 & 3,01 & 107 & 80,45 & 22 & 16,54 & 133 \\
\hline$Y_{1.2}$ & - & - & - & - & 4 & 3,01 & 103 & 77,44 & 26 & 19,55 & 133 \\
\hline$Y_{1.3}$ & - & - & - & - & 9 & 6,77 & 104 & 78,20 & 20 & 15,04 & 133 \\
\hline
\end{tabular}

Sources: Primary data 
Table 8 describes the respondents perception on customer satisfaction (Y1) of Pos Ekspres performance, it can be described as follow,

1. Overall Satisfaction (Y1.1), 3.01\% of respondents answered neutral, $80.45 \%$ answered agree, and $16.54 \%$ answered strongly disagree. This shows that the majority of respondents (96.99\%) had the satisfaction of general or overall performance of Pos Ekspres.

2. Confirmation - Expectancy (Y1.2), 3.01\% of respondents answered neutral, $77.44 \%$ answered agree, and $19.55 \%$ answered strongly disagree. Thus the majority of respondents (96.99\%) have felt the expectation has been fulfilled.

3. Ideal Situation for Comparison (Y1.3), $6.77 \%$ of respondents answered neutral, $78.2 \%$ answered agree, and $15.04 \%$ answered strongly agreed, meaning that the majority of respondents (93.23\%) have feel the ideal situation.

Table 9: Respondents Frequency Distribution Rate on Customer Loyalty (Y2)

\begin{tabular}{|c|c|c|c|c|c|c|c|c|c|c|c|}
\hline \multirow{3}{*}{ Indicators } & \multicolumn{10}{|c|}{ Respondents Score } & \multirow{3}{*}{ Total } \\
\hline & \multicolumn{2}{|c|}{1} & \multicolumn{2}{|c|}{2} & \multicolumn{2}{|c|}{3} & \multicolumn{2}{|c|}{4} & \multicolumn{2}{|c|}{5} & \\
\hline & $\mathrm{F}$ & $\%$ & $\mathrm{~F}$ & $\%$ & $\mathrm{~F}$ & $\%$ & $\mathrm{~F}$ & $\%$ & $\mathrm{~F}$ & $\%$ & \\
\hline$Y_{1.1}$ & - & - & - & - & 4 & 3,01 & 107 & 80,45 & 22 & 16,54 & 133 \\
\hline$Y_{1.2}$ & - & - & - & - & 4 & 3,01 & 103 & 77,44 & 26 & 19,55 & 133 \\
\hline$Y_{1.3}$ & - & - & - & - & 9 & 6,77 & 104 & 78,20 & 20 & 15,04 & 133 \\
\hline
\end{tabular}

Sources: Primary data

Table 9 presents information about respondents' statements of Customer Loyalty indicators. Based on these data, it can be explained as following:

1. Say the kindness of product to others (Y2.1), 2.26\% of respondents answered neutral, $86.47 \%$ answered agree, and $11.28 \%$ answered strongly agree, which means the majority of respondents $(97.74 \%)$ intend to say goodness Pos Ekspres to others.

2. Recommend products to friends or others (Y2.2), which is 1.5\% of respondents answered neutral, $87.22 \%$ answered agree, and $11.28 \%$ answered strongly disagree. This means that the majority of respondents (98.50\%) intend to recommend products to friends or other people.

3. Re-purchase (Y2.3), 3.76\% replied neutral, $78.2 \%$ answered agree, and $18.05 \%$ answered strongly agreed, that the majority of respondents (96.24\%) intend to make repeat purchases Pos Ekspres.

\subsection{Data Analysis}

\subsubsection{Assumptions and SEM Feasibility Model Test}

The SEM models generated in this study meet all SEM model assumptions which are normal multivariate data, nothing happens multikolinieritas or singularity, and does not happen outlier in the data. This is shown by the results of the testing of normality (CR) gives a CR value of 1.783 lies between $-1.96 \leq C R \leq 1.96$ (á $=0.05$ ), which means the data is multivariate normal. In addition, the data also demonstrated by the normal univariate all grades critical ratio of all indicators located between $-1.96 \leq \mathrm{CR} \leq 1.96$. Test multikolinieritas provide value determinant of the sample covariance matrix at 34.022 , so there is no problem of multikolinieritas and singularity on the analyzed data. Outlier test results showed none of the cases that have a value greater than the distance Malahnobis 30.144 ( $x 2$ value: $d f=10 ; a=0,05$ ), so that it can be concluded there was no multivariate outlier in research data.

The fitness model test result shows that the SEM model meet the seven criteria of eight eligibility SEM models, and there is one criteria were feasible. The results of the feasibility SEM model test are X2count $=92.264<x 2$ table, $\mathrm{df}=81=$ 103.00951 (worthy), Sig. Probability $=0.106>0.05$ (feasible); GFI $=0.918 \geq 0.90$ (feasible); RMSEA $=0,069 \leq 0.08$ (feasible); $\mathrm{X} 2$ / df $=1.636 \leq 2$ or 3 (feasible); TLI = $0.935 \geq 0.90$ (feasible); CFI $=0.922 \geq 0.90$ (decent), and AGFI = 0.897 (feasibly approached) in which it should have a decent AGFI $\geq 0.90$. Based on these results of the feasibility model test, the SEM models are feasible. It means there is a match between the model with the data. 


\subsubsection{Hypothesis Testing}

Table 10 presents the results of causality hypothesis test

Table 10: Causality Test Results

\begin{tabular}{ccccccc}
\hline \multicolumn{3}{c}{ Variables } & Path Coefficients & CR & Probabilities & Hypothesis \\
\hline $\mathrm{X}_{1}$ & $\rightarrow$ & $\mathrm{Y}_{1}$ & 0,627 & 4,031 & 0,000 & accepted (positive significant) \\
$\mathrm{X}_{2}$ & $\rightarrow$ & $\mathrm{Y}_{1}$ & 0,445 & 3,436 & 0,000 & accepted (positive significant) \\
$\mathrm{X}_{3}$ & $\rightarrow$ & $\mathrm{Y}_{1}$ & 0,311 & 2,523 & 0,011 & accepted (positive significant) \\
$\mathrm{X}_{1}$ & $\rightarrow$ & $\mathrm{Y}_{2}$ & 0,501 & 3,887 & 0,000 & accepted (positive significant) \\
$\mathrm{X}_{2}$ & $\rightarrow$ & $\mathrm{Y}_{2}$ & 0,333 & 2,612 & 0,002 & accepted (positive significant) \\
$\mathrm{X}_{3}$ & $\rightarrow$ & $\mathrm{Y}_{2}$ & 0,181 & 1,687 & 0,085 & rejected (positively not significant) \\
$\mathrm{Y}_{1}$ & $\rightarrow$ & $\mathrm{Y}_{2}$ & 0,724 & 5,801 & 0,000 & accepted (positive significant) \\
\hline
\end{tabular}

Souces: Data Analysis with AMOS Version 18

\subsubsection{The Influence of Service Quality on Customer Satisfaction}

Based on the hypothesis test results (Table 10), Hypothesis 1 stated that Service Quality of Pos Ekspres have a significant positive effect on customer satisfaction Pos Ekspres in East Java is accepted. The acceptance of hypothesis 1 is shown by the positive path coefficient of 0.627 with $C R$ amounted to 4.031 with a probability less than the value $a(p=$ $0.000<0.05)$. This may imply that the better quality of service Pos Ekspres, the higher customer satisfaction Pos Ekspres will increase and conversely, the worse the quality of service Pos Ekspres, the lower customer satisfaction Pos Ekspres will decline. This finding means that the performance service quality provided by Pos Ekspres have meet customer expectations.

The acceptance of hypothesis 1 can explain the evaluation of service quality associated with satisfaction. Positive evaluation of service quality will rise satisfaction, while a negative evaluation service quality of will cause dissatisfaction. Empirically, this finding is supported by the fact that the characteristics of the respondent majority women ages 20 years to 30 years. Women customers have a nature want to be noticed and served. Customers aged 20 to 30 years are the productive age customers who have a high activity which demanding service of others in accelerating the completion of their work. Customer group with these characteristics is a group of customers who tend to have high expectations or expectations of the good quality service, which in turn will affect the satisfaction of customer perceived service. Customers are very concerned about the dimensions of service quality that include physical evidence, reliability, responsiveness, assurance, empathy which in turn it can help customers in the process of shipments of their goods or documents. It is also supported by the results of studies showing that the majority of respondents have a positive perception to the dimensions of services quality provided, and the majority of customers are satisfied and very satisfied (delight) with the service quality of Post Express in East Java.

\subsubsection{The Influence of Price on Customer Satisfaction}

The result of hypothesis test at Table 10 are receiving Hypothesis 2 which is stated Price Pos Ekspres have significant positive effect on customer satisfaction Pos Ekspres in East Java. It can be prove with the positive path coefficient of 0.445 with $\mathrm{CR}$ amounted to 3,436 with $p=0,000<a=0.05$. This finding meant that the better the price Pos Ekspres according to the customer (more affordable, matching to quality, cheaper than the competition), the higher the customer satisfaction will get and conversely, the worse the price of Pos Ekspres, the lower the customer satisfaction Post Express will decrease. Thus the price has an effect on customer satisfaction, as they can be used by consumers to measure the service quality provided by the company. An appropriate pricing will form a positive customer perception of the quality and positive customer perception will give the customer a sense of complacent.

This finding is also supported by the data in Table 6, which shows that the majority of respondents rates the price of Pos Ekspres already meet the customer expectation (low prices, matching to the quality and competitive prices). Thus the customer feels that there is a match between Pos Ekspres services benefits they receive with the sacrifice they have given. The meet of consumer expectation and their perceived causes satisfaction. 


\subsubsection{The Influence of Brand Image on Customer Satisfaction}

Table 10 provides an information that hypothesis 3 which states Pos Ekspres brand image were have significant positive effect on customer satisfaction Pos Ekspres in East Java is accepted. This results is demonstrated by positive path coefficient value of 0.311 with CR amounted to 2,523 with $p=0.011<0.05$. It means the better Pos Ekspres brand image in the eyes of customers the higher customer satisfaction will increase and vice versa the bad Pos Ekspres brand image will degrade the Pos Ekspres customer satisfaction. A famous brand image will help to improve customer satisfaction, which in turn it can create customer loyalty. Company which have a product with a strong brand image will get a better position, they can sustain a competitive advantage and increase their market share.

Table 7 reveals that majority of respondents Pos Ekspres has a good brand image in their minds. A good brand image will form a positive brand association in the minds of consumers, so a good brand image of Pos Ekspres will provide a guarantee for the customer to satisfy their needs. We can also state that a good image will make customers feel happy to use the services of Post Express, this sense of excitement will give them a customer satisfaction.

\subsubsection{The Influence of Quality Service to Customers Loyalty}

Hypothesis 4 which states the service quality of Pos Ekspres have significant positive effect on customer loyalty is accepted as well. The acceptance of the hypothesis 4 is indicated by a positive value of 0.501 coefficient lines with CR amounted to $3.887, p=0.000<0.05$. This result gives the sense that the quality of service Pos Ekspres is getting better, in turn it will improve the customer loyalty of Pos Ekspres, on the contrary, the worst the service quality of Pos Ekspres will decrease Pos Ekspres customer loyalty. Evaluation of the service quality associated with satisfaction, it will lead to desire to use company services in the future. Consumer evaluation of the service quality lies in the balance of expectations and perceptions of services provided. The perception which are met or even exceed expectations will result in the evaluation of service quality is ideal. Conversely, if expectations are not met with perception, it will produce a negative evaluation of service quality. A satisfied customer will perform some kind of action in expressing his satisfaction, they will have an interest to repurchase in the future.

These findings are also supported by the empirical data in Table 7. It shows that the majority of respondents rate the service quality received above the median value (above 3 ) which gives a value of 4 and 5 . This finding indicates that the services quality which customer received are exceeding their expectations, so customers feels very pleased (high satisfaction), and in turn these feeling will create customer loyalty.

\subsubsection{The Influence of Price on Customers Loyalty}

Hypothesis 5 stated the Price of Pos Ekspres have significant positive effect on customer loyalty of Pos Ekspres in East Java is accepted. The acceptance of the hypothesis 5 is indicated by a positive path coefficient of 0.333 with CR amounted to 2.612 with $p=0.002<0.05$. This situation means if the price of Pos Ekspres is good in the eyes of customers, it will increase Pos Ekspres customer loyalty and vice versa, if the price of Pos Ekspres getting worst, it will lower Pos Ekspres customer loyalty. A fair prices have significant and positive effect on satisfaction and also directly affect loyalty. It also has indirect affect to loyalty mediated by satisfaction.

This finding is reinforced by the data in Table 8 of customer ratings on Pos Ekspres prices, that most respondents rate the price of Pos Ekspres above the midpoint (above 3) which gives a value of 4 and 5 . These results indicate that the price of Pos Ekspres exceed the benefits provided, affordable by customers, and the price is competitive compared to the competitors. Such price conditions will create customer loyalty.

\subsubsection{The Influence of Brand Image on Customers Loyalty}

Based on Table 10, hypothesis 6 which states Pos Ekspres brand image have significant positive effect on Pos Ekspres customer loyalty in East Java is rejected. It happens as indicated by a positive path coefficient value of 0.181 with CR amounted to 1,687 with $p=0.085>0.05$ ). This finding means the Pos Ekspres brand image significantly do not able to create Pos Ekspres customer loyalty in East Java. The successful brand image is a brand image that allows consumers to identify their needs that can be satisfied with a specific brand and comparing with other competitors. The competition of today's businesses in getting consumers are no longer limited to the functional attributes attached to the product, such as benefits or usefulness of the product to be consumed, but has been associated with a brand that is able to provide a special image for the user. 
This situation happens because the Post Express is a relatively new product from PT. Pos Indonesia (Persero). The brand image of Post Express is not yet developed to the public customer. Table 4 support this finding, the majority of customers sometime uses Post Express about two or three times. The Pos Ekspres brand image is not directly affected loyalty, but indirectly. Pos Ekspres brand image goes through the mediation of customer satisfaction have a significant positive effect on customer loyalty.

\subsubsection{The Influence of Customer Satisfaction on Customers Loyalty}

Hypothesis 7 is also accepted. Table 10 shows a positive path coefficient of 0.724 with $\mathrm{CR}$ amounted to 5.801 and $p=$ $0.000<0.05$, Pos Ekspres customer satisfaction have significant positive effect on Pos Ekspres customer loyalty in East Java. It can be argued that the higher Pos Ekpres customer satisfaction will increase Pos Ekspres customer loyalty and conversely, the lower Pos Ekspres customer satisfaction will reduce the Pos Ekspres customer loyalty. Customer satisfaction is a very important part in customer loyalty. Customer loyalty is reflected by repurchasing and recommendations to others. Satisfied consumers will continue to buy the product, use it even tell others of the advantages of these products based on their experience in using the product. Customer satisfaction should be maintained and enhanced in order to create and maintain customer loyalty. Customer loyalty is a proof of commitment which is strongly held by customers to buy again a certain products or services in the future.

This finding is supported by the data in Table 8, almost all customers expressed high satisfaction (score of 4 and 5) on the performance of Pos Ekspres. They feel the performance of Pos Ekpres exceed the expect performance. These high satisfaction raises the surprising feeling of emotional satisfaction and in turn an emotional satisfaction will create customer loyalty. From this poin of view, the Pos Ekpres customer in East Java has a high satisfaction and delight, so it make them a loyal customers.

\section{Conclusion}

Service Quality has significant positive effect on Pos Ekspres customer satisfaction in East Java. This means that the better service quality of Pos Ekspres will lead to the increase of Pos Ekspres customer satisfaction or conversely, the worse the Pos Ekspres service quality will lead to lower Pos Ekspres customer satisfaction. This finding means that the performance of Pos Ekspres service quality have met their customer expectations.

Price has significant positive effect on Pos Ekspres customer satisfaction in East Java. This means, the better Pos Ekspres prices according to the customer more affordable, matching to quality, cheaper than the competition), the higher the customer satisfaction will get and conversely, the worse the price of Pos Ekspres, the lower the customer satisfaction Post Express will decrease. This finding means the price offered by Pos Ekspres is already meet with the product quality, affordable by the customer, and able to compete with competitors.

Brand image has significant positive effect on Pos Ekspres customer satisfaction in East Java. This means that the good image of the brand, will lead Pos Ekspres customer satisfaction to increase or vice versa, the worse Pos Ekspres brand image will lower Pos Ekspres customer satisfaction. This finding reveals that Pos Ekspres brand image is able to establish a positive brand association in the minds of their customers, so customers feels a guarantee to get satisfaction.

Service quality has significant positive effect on Pos Ekspres customer loyalty in East Java. This result can be concluded that the better the service quality will lead to increase customer loyalty or vice-versa, the worse the service quality will decrease customer loyalty. These findings indicate the Pos Ekspres service quality received by customers has exceeded customer expectations, so customers feel very happy with high satisfaction and thus feeling of being very happy will make customers loyal.

Price has significant positive effect on Pos Ekspres customer loyalty in East Java. This may imply that the better price (matching quality, affordable, competitive) in the eyes of customers, will lead to increase customer loyalty or otherwise, the worse the price, will lead to lower customer loyalty. These results indicate that the Pos Ekspres price exceed the benefits, affordable, and remain competitive compared to the competitors' prices, thereby it cause customers become a loyal customers.

Brand image has not significant positive effect on Pos Ekspres customer loyalty in East Java. This finding means that the Pos Ekspers brand image have no direct significant influence on customer loyalty. The finding reveal the indirect influence of brand image through customer satisfaction on customer loyalty.

Customer satisfaction also has significant positive effect on Pos Ekspres customer loyalty in East Java. This may imply higher customer satisfaction will increase customer loyalty or vice-versa, the lower customer satisfaction will reduce customer loyalty. The result means the Pos Ekspers customer in East Java have earned high satisfaction and delight for 
the Pos Ekspers performance, thus creating a customer loyalty.

\section{Research Contributions and Further Research Recommendations}

This study will provide theoretical contributions as additional reference in building a more comprehensive understanding of the relationship of organization in an effort to create customer loyalty services company. This study also provides a practical contributions that demonstrate how a service company benefit from the implementation of service quality, pricing, and build their brands in the satisfaction and loyalty of its customers.

For further research, there is an opportunity to develop this research in different settings by using probability sampling method, so it can be more widely generalized.

\section{References}

Aaker, David, A. and Keller. (1990). Consumer Evaluation of Brand Extention. Journal of Marketing, Vol. 54: 27.41.

Aryani, D. dan Rosita, F. (2010). Pengaruh Kualitas Layanan terhadap Kepuasan Pelanggan dalam membentuk Loyalitas Pelanggan. Jurnal IImu Administrasi dan Organisasi, Vol. 17 (2):114-126.

Bei, L.T. and Chiao, Yu-Ching. (2001). An integrated model for the effects of perceived product, perceived service quality,and perceived price fairness on consumer satisfaction and loyalty. Journal of Consumer Satisfaction, Dissatisfaction and Complaining Behavior. Vol. 14: 125-141.

Bennet, R., a n d Rundle-Thiele. S. (2004). Customer satisfaction should not be the only goal. Journal of Service Marketing, Vol. 18(7): 514-523.

Caruana, A. (2002). Service Loyalty. The Effect of Service Quality and The Madiating Role of Customer Satisfaction. European Journal of Marketing, Vol. 36:811-828.

Cronin, Joseph J., and Steven A. Taylor. (1992). Measuring Service Quality: A Reexamination and Extention. Journal of Marketing, Vol. 56 (July): 55-68.

Dekimpe, M. G., Steenkamp , J. B. E. M., Mellens, M., and Abeele, P. V. (1997). Decline and Variability in Brand Loyalt y. International Journal of Research in Marketing, Vol. 14(5): 405-420.

Dimyati, Mohamad. (2011). Theoretical Testing on Service Quality and Product Innovation of Small-Micro Credit Banks (Case Study). Journal Of Economics, Business, \& Accountancy Ventura, Vol. 14(3), December, 225-238.

Dimyati, Mohamad. (2015). The Role of Customer Satisfaction in Mediating Marketing Communication Effect on Csutomer Loyalty. Researchers World: Journal Of Arts Science and Commerce:International Refereed Research Journal, Vol. VI Issue 4(1), October, 75-87.

Engel, James F., et al. (1993), Consumer Behavior. Seventh Edition. Orlando: The Dryden Press.

Ferdinand, A. (2006). Metode Penelitian Manajemen. Edisi 2. Semarang: Universitas Diponegoro

Fornell, C. et. al., (1996). The American Customer Satisfaction Index: Nature, purpose and findings. Journal of Marketing, Vol. 6 (4)::621.

Fullerton, G., and Taylor, S. (2002). Mediating, Interactive, and Non Linear Effects in Service Quality and Satusfaction with Services Research. Canadian Journal of Administrative Science. Vol. 19 (2): 124-136.

Ghozali, I. (2004). Model Persamaan Struktural. Konsep dan Aplikasi Program Amos Ver. 5.0. Semarang: Badan Penerbit UNDIP

Griffin, Jill. (2002). Customer Loyalty How to Earn It, How to Keep It. Kentucy: McGraw-Hill.

Hidayat, R. (2009). Pengaruh Kualitas Layanan, Kualitas Produk dan Nilai Nasabah terhadap Kepuasan dan Loyalitas Nasabah Bank Mandiri. Jurnal Manajemen dan Kewirausahaan, Vol. 11 (1) : 59-72.

Hsieh, M.H., Pan,S.L. and Setiono, R. (2004). Product, Corporate and Country Image Dimensions and Purchase Behavior. A Multicountry Analisys. Journal of Academy of Marketing Science, Vol. 32 (3): 251-270.

Indriantoro, Nur, dan Bambang, Supomo. (2002). Metodologi Penelitian Bisnis. Edisi Pertama, Yogayakarta: BPFE UGM.

Jahanshahi, A.A., Gasthi, Mirdamadi, S.A., Nawaser, K., Khaksar, S.M.S. (2011). Study the Effect of Customer Service and Product Quality on Customer Satisfaction and Loyalty. International Journal of Humanities and Social Science. Vol.1 (7): 253-260

Jones, Thomas O., and Sasser W. Earl Jr. (1995). Why Satisfied Customer Defect. Harvard Business Review, Vol.73 No.6,pp.88-100.

Kapferer, J. N. (2005). The roots of brand loyalt y decline: An international comparison. Ivey Business Journal, Vol.69(4): 1-6.

Keller, K. L. (1993). Conceptualizing, measuring, and managing customer- based brand equity. Journal of Marketing, Vol 57(1): 1-22.

Kotler, Philip. (2008). Prinsip-prinsip Pemasaran. Edisi 12. Jilid 1. Jakarta: Erlangga

Kotler, Philip. dan Amstrong, G. (2012). Principles of Marketing 14e. Pearson International Edition, Upper Saddle River, New Jersey: Pearson Prentice Hall Inc.

Kotler, Philip and Kevin, Lane Keller. (2006). Marketing Management 12e, Pearson International Edition, Upper Saddle River, New Jersey: Pearson Prentice Hall Inc.

Mahmud, A., Jussof, K., and Hadijah, St. (2013). The Effect of Service Quality and Price on Satisfaction and Loyalty of Customer of Commercial Flight Service Industry. World Applied Sciences Journal, Vol. 23 (3): 354-359.

Nirwana. (2006). Service Marketing Strategy. Cetakan Pertama. Malang: Dioma.

Oliver, Richard L. (1997). Satisfaction: A Behavioral Perspective on The Consumer. New York: The McGraw-Hill Companies. Inc. 
Ostrowski, P.L., Brien, T. and Gordon, G.H. (1993). Service Quality and Customer Loyalty in the Commercial Airline Industry. Journal of Travel Research. October, Vol $32: 16-24$.

Parasuraman, V., Zeithaml A. and Berry, L.L. (1985). A Conceptual Model of Service Quality and its Implication for Future Research. Journal of Marketing Research. Vol. $49: 41-50$.

Parasuraman, V., Zeithaml A. and Berry, L.L. (1998). Servqual a Multy Item Scale for Marketing Consumer Perceptions of Service Quality. Journal of Retailing. Vol. 64:12-40.

Schultz, D. E. (2005). The Loyalt y Paradox. Marketing Management. Vol.14(5): 10-11.

Sekaran, Uma. (2003). Research Methods for Business: A Skill Building Approach. USA: John Wiley and Sons Inc.

Selnes, F. (1993). An Examination of The Effect of Product Performance on Brand Reputation, Satisfaction, Satisfaction and Loyalty. Europan Journal of Marketing, Vol. 27 (9) :19-35.

Shimp, Terence. (2003). Periklanan Promosi \& Aspek Tambahan Komunikasi Pemasaran Terpadu, Jilid I ( edisi 5). Jakarta : Erlangga.

Simamora, B. (2003). Memenangkan Pasar dengan Pemasaran Efektif dan Profitable. Jakarta: Gramedia Pustaka Utama.

Swastha, B. dan Irawan. (2005). Manajemen Pemasaran Modern. Yogyakarta: Liberty.

Thakur, S. and Singh, A.P. (2012). Brand Image, Customer Satisfaction and Loyalty Intention: A Study in the Context of Cosmetic Product among the People of Central India. International Journal of Multidisplinary Management Studies, Vol.2 (5): $2249-8834$.

Tjiptono, F. (2012). Startegi Pemasaran. Malang: Bayu Media Publishing.

Tu, T. Y. Wang, C.M., and Chang, H.C. (2012). Corporate brand Image an Customer Satisfaction on Loyalty. An Empirical Study of Starbucks Coffee in Taiwan. Journal of Social and Developmnet Sciences, Vol.3 (1) : 24-32.

Undang-Undang RI No. 38 Tahun 2009 tentang Pos. (http://www.bumn.go.id/ data/ uploads/ files/1/38.pdf, visited on 14 September 2014).

Voss, G.B., Parasuraman and Grewal, D. (1998). The Roles of Prices, Performance and Expectations in Determining Satisfaction in Service and Exchanges. Journal of Marketing, Vol. 62:46-61.

Widjaya, H.N. (2002) Mengungkap Sukses Hypermarket. Jakarta: Pikiran Rakyat Cyber Media.

Yulisetiarini, Diah. (2016). The Effect of Relationship Marketing toward Customer Satisfaction and Customer Loyalty on Franchised Retail in Est Java. Mediterranean Journal of Social Sciences, Vol. 7(1): 333-339.

Zeithaml, V. (1988). Consumer Perceptions of Price, Quality, and Value : A Means - End Model and Synthesis of Evidence, Journal of Marketing, Vol 52. :2 -22.

Zeithaml, V. A., and Bitner, M. J. (1996). Services Marketing. $1^{\text {st }}$ edition. New York: McGrawHill.

Zeithaml, V.A., Parasuraman, A., and Berry, L.L. (1996). The Behavioral Consequences of Service Quality. Journal of Marketing, Vol 60.(2). (April): 31-46. 